History. The specimen, which is now in the collection of the National Museum of Canada (NMC No. 8224), indicates a more eastern range in that part of the province than was previously known. This was the second extreme northern $\mathrm{Saskatchewan}$ record. The first specimen from the area (NMC No. 5087) was collected on June 25, 1960, about 100 miles to the west on the north side of Lake Athabasca and five miles south of Uranium City by R. W. Nero. The nearest record to Lake Athabasca in the south of the province is a tadpole (NMC No. 6243) collected at Flotten River at Highway 4 on July 6 , 1962 by F. R. Cook and C. B. Powell of the National Museum. Undoubtedly the species is to be expected in the area between Flotten River and Lake Athabasca.

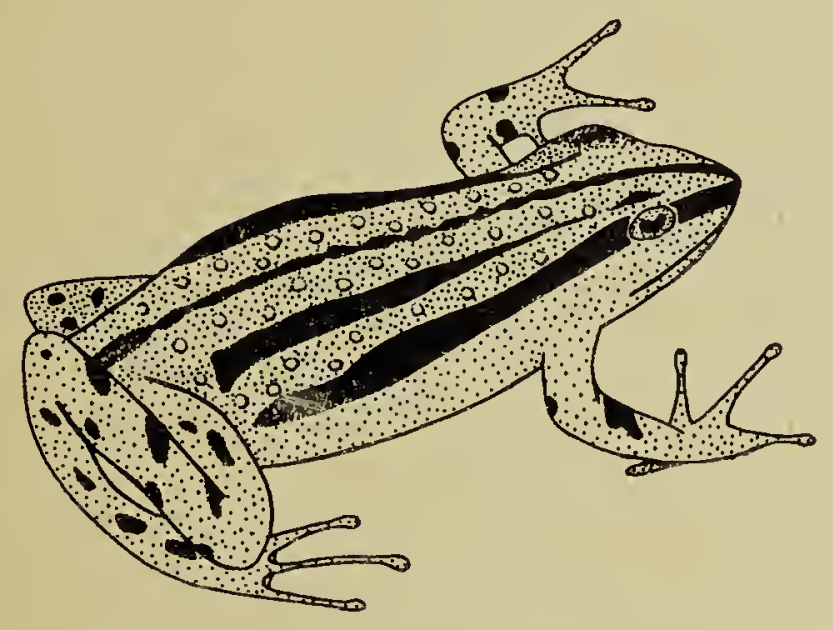

Boreal Chorus Frog

Nero reported that in 1960 Boreal Chorus Frogs were first heard calling on May 17. The Stony Rapids specimen was full of eggs when it was collected on July 7 , which seems to indicate a fairly long breeding season for the species in the northern part of the province as is the case in southern Saskatchewan.

\section{BUTTERFLY DISCOVERIES OF 1964}

\section{by Ronald Hooper, Punnichy}

Butterfly collecting in 1964 in Saskatchewan was rather poor owing to the extremely dry weather in the early part of the season. However, I managed to collect three species that I had not previously taken. Two of these were found during a very interesting trip into extreme northeastern
Saskatchewan for the Saskatchewan Museum of Natural History. On this trip I collected 26 species of butterflies and over 1200 insects in all, chiefly at Stony Rapids; Black Lake, and Charcoal Lake. The latter lake lies northeast of Wollaston Lake on the Cochrane River system. I visited Charcoal Lake through the courtesy of Gary Anweiler who was conducting an ornithological survey for Dr. R. Nero. The three species of butterflies that I collected for the first time are listed below. Identifications were made by C. F. Dos Passos, Mendham, New Jersey, a noted authority.

Palaeno Sulphur (Colias palaeno chippewa)-One female collected near Stony Rapids, July 10. One male collected by G. Anweiler at Black Lake, July 26. My brother, Donald Hooper, collected several specimens of this species at Lynn Lake, Manitoba, on July 12 and 20, 1956. The species is also reported for northern Alberta, so it is expected that it would occur across northern Saskatchewan.

Yukon Blue (Plebeiuds optilete yukona) -Fairly common in damp, grassy places (particularly along stream beds) at Stony Rapids and Black Lake, July 7 to 25. A fair number were collected. This species also is reported from northern Manitoba and Alberta and is therefore to be expected throughout northern Saskatchewan.

Eryphon or Western Pine Elfin (Incisalia eryphon sheltonensis)-I collected several fresh Pine Elfins in the Cypress Hills Park on June 1, 1964. I picked out the two that looked most like Eryphon and sent them for identification; they were confirmed as being I. eryphon. The others may be I. eryphon or I. niphon (the Eastern Pine Elfin). Pine Elfins that I collected in the same area in June, 1963, turned out to be Incisalia niphon clarki. The Eastern Pine Elfin has been taken in several localities in central Saskatchewan, but it is not on the Alberta check-list. The Western Pine Elfin is recorded in Alberta only from the Rockies and the Foothills. It is also reported from Miles City, Montana, and extreme southwestern North Dakota. According to Dos Passos, it is possible that Incisalia niphon and $I$. eryphon are different subspecies of the same species. 